\title{
Model Pendidikan Agama Kristen Berwawasan Majemuk dalam Membina Sikap Toleransi Beragama di Indonesia
}

\author{
Fredik Melkias Boiliu1*, Desetina Harefa2, Haposan Simanjuntak², \\ Septianus Waruwu ${ }^{4}$, Irfan F. Simanjuntak ${ }^{5}$ \\ 1,2,3,4,5Sekolah Tinggi Teologi REAL, Batam \\ *Correspondence: boiliufredik@gmail.com
}

\begin{abstract}
This article discusses the model of christian religious education with a compound insight in fostering religious tolerance in Indonesia. In the context of nationhood, society and religion in Indonesia according to the basis of Pancasila, there are six recognized religions, namely Islam, Christianity, Catholicism, Hinduism, Buddhism and Confucianism. Religious differences are supposed to acknowledge each other, respect each other, and cooperate in virtue. But in fact differences in religious beliefs become a driving factor to bring down, demean each other, or mix between religions with each other. Therefore, there needs to be a diverse religious insight in fostering religious tolerance in Indonesia. Therefore, the model of Christian religious education is inclusive, multicultural, dialogue and peaceful as the right approach to foster religious tolerance in daily life. This research uses a method of literature study that refers to concepts and theories according to literature available such as articles published in various scientific journals, books and other scientific papers.
\end{abstract}

Keywords: Christian religious education; dialogue; multicultural; tolerance

\begin{abstract}
Abstrak. Artikel ini membahas tentang model pendidikan agama Kristen berwawasan majemuk dalam membina sikap toleransi beragama di Indonesia. Dalam konteks berbangsa, bermasyarakat dan beragama di Indonesia sesuai dasar Pancasila, ada enam agama yang diakui yaitu Islam, Kristen, Katolik, Hindu, Budha dan Konghucu. Perbedaan agama seharusnya untuk saling mengakui, saling menghormati, dan bekerja sama dalam kebajikan. Namun pada faktanya perbedaan keyakinan agama menjadi faktor pendorong untuk saling menjatuhkan, saling merendahkan, atau mencampuradukkan antaragama yang satu dengan yang lain. Oleh sebab itu, perlu adanya wawasan agama yang mejemuk dalam membina sikap toleransi beragama di Indonesia. Untuk itu, model pendidikan agama Kristen yang inklusif, multikultural, dialog dan damai sebagai pendekatan yang tepat untuk membina sikap toleransi beragama dalam kehidupan sehari-hari. Penelitian ini menggunakan metode kajian pustaka yang merujuk pada konsep dan teori sesuai literature yang tersedia seperti artikel-artikel yang dipublikasikan dalam berbagai jurnal ilmiah, buku-buku dan makalah ilmiah lainya.
\end{abstract}

Kata kunci: dialog; multikultural; pendidikan agama Kristen; toleransi

\section{PENDAHULUAN}

Konflik antar umat beragama di Indonesia merupakan masalah yang sangat merisaukan semua pemeluk agama dan tentu hal ini menjadi pergumulan kita semua. Buyung Syukron mengatakan bahwa permasalahan agama merupakan fenomena 
transnasional yang diibaratkan seperti dua sisi mata uang berpotensi menghadirkan harmoni dan konflik. ${ }^{1}$ Selaras dengan ini, Firdaus M Yunus menjelaskan bahwa konflik antar umut beragama disebab oleh cara pandang seseorang terhadap agama itu sendiri yang akan memunculkan banyak permasalahan. ${ }^{2}$ Menurut St. Aisyah BM konflik antar umat beragama disebabkan oleh ketidakmampuan seseorang untuk menerjemahkan pesan wahyu yang mengakibatkan hilangnya orientasi atau ketidakpastian, dan bahkan putus asa. Bagi Aisyah penyebab konflik juga disebabkan oleh faktor politik, kesenjangan ekonomi, kesenjangan budaya, sentiment etnis dan agama. ${ }^{3}$ Dengan demikian, konflik umat antar beragama di Indonesia dapat disebabkan oleh cara pandang yang salah, memiliki pemahaman yang sempit dalam beragama, kepentingan pribadi dan kepentingan kelompok lainnya.

Terkait dengan Konflik antar umat beragama yang sering terjadi di indonesia, maka berikut ini beberapa permasalahan yang terjadi yaitu sebagai berikut: Pertama penyerangan terhadap kelompok Islam Syi'ah terjadi pada Minggu, 26 Agustus 2012 di Dusun Nanggernang, Desa Karang Gayam, Kecamatan Omben, Sampang, Madura sekitar pukul 11.00 WIB. Akibat dari peristiwa ini, seorang warga dinyatakan tewas, lima orang luka, dan empat di antara korban luka dalam kondisi kritis. Kedua, pembakaran gereja di Aceh Singkil pada 13 Oktober 2015, yang terjadi bentrok antarwarga di Kecamatan Gunung Meriah, Kabupaten Aceh Singkil, Nangroe Aceh Darussalam (NAD) berimbas pada pembakaran sebuah gereja dan menewaskan dua orang warga, serta empat orang luka-luka. Dari dugaan sementara pihak kepolisian, motif peristiwa tersebut berkaitan dengan pemilihan kepala daerah (pilkada) di wilayah tersebut. ${ }^{4}$ Ketiga, konflik/kekerasan sosial Tolikara pada 17 Juli 2015. Pada tanggal hari itu, pukul 07:00 WIT, bertempat di lapangan Makoramil 1702-11/Karubaga Distrik Karubaga, kabupaten Tolikara telah berlangsung kegiatan shalat idul fitri $1436 \mathrm{H}$ yang dipimpim oleh Ustad Junaedi; dan berujung pada keributan antara Jemaat GIDI yang sedang melaksanakan seminar internasional yang dipimpin oleh Pendeta Marthen Jingga dan Harianto Wanimbo (Korlap) dengan Umat muslim yang sedang melaksanakan shalat Ied. ${ }^{5}$ Keempat, konflik SARA di Tanjung Balai, Asahan, Sumatera Utara, pada 30 Juli 2016, yang bermula dari seorang wanita keturunan Tionghoa M (41) yang mengajukan protes pada takmir Masjid Al-Makhsum, untuk mengecilkan volume suara azan di Masjid, karena merasa terganggu. Teguran tersebut katanya telah dilayangkan beberapa kali. Beberapa waktu kemudian datang takmir masjid bersama jamaah mendatangi M di rumahnya, Jalan Karya, Tanjung Balai, pada Jumat

\footnotetext{
${ }^{1}$ Buyung Syukron, 'Agama Dalam Pusaran Konflik (Studi Analisis Resolusi Terhadap Munculnya Kekerasan Sosial Berbasis Agama Di Indonesia)', RI'AYAH, 2.2 (2017), 1-27.

2 Firdaus M Yunus, '“Konflik Agama Di Indonesia Problem Dan Solusi Pemecahannya,"' Substantia, 16.2 (2014), 217-28.

3 St. Aisyah BM, 'Konfik Sosial Dalam Hubungan Antar Umat Beragama', Jurnal Dakwah Tabligh, 15.2 (2014), 189-208.

4 Syukron.

5 Retnowati, 'Agama, Konflik Dan Integrasi Sosial Refleksi Kehidupan Beragama Di Indonesia: Belajar Dari Komunitas Situbondo Membangun Integrasi Pasca Konflik', Sangkep Jurnal Sosial Keagamaan, 1.1 (2018), 3-28.
} 
29 Juli 2016.6 Kelima, pembubaran Kebaktian Gereja Pra-Natal di Bandung, ada 6 Desember 2016. Pembubaran acara pra-Natal di Sabuga, Bandung, Selasa (06/12) malam oleh kelompok intoleran, yang menggunakan alasan perizinan yang belum lengkap, dan ini menurut aktivis keberagaman dinilai sebagai alasan 'mengada-ada'.7

Terkait dengan konflik antar umat beragama di Indonesia, maka perlu adanya pendidikan agama yang berwawasan majemuk dalam membina sikap toleransi beragama. Oleh sebab itu, penelitian ini merujuk pada beberapa penelitian terdahulu tentang pendidikan agama yang berwawasan majemuk. Penelitian Ricky Santosa Muharam tentang "membangun toleransi umat beragama di Indonesia berdasarkan konsep deklarasi Kairo". Penelitian ini menggunakan metode kualitatif deskriptif analisis dan hasil penelitian menunjukkan bahwa nilai-nilai toleransi harus dipraktekan dalam kehidupan sehari-hari di Indonesia. ${ }^{8}$ Ada Penelitian Herman Mohamad Rijal tentang pembinaan toleransi antar umat beragama dalam perspektif pendidikan agama Islam bagi remaja di kota Kendari. Penelitian ini menggunakan metode kualitatif deskriptif dan hasil penelitian menujukkan bahwa perlu adanya kesadaran remaja untuk menghargai sesama yang beragama lain, membantu sesama yang membutuhkan walaupun berbeda agama, tidak mencela agama lain dan membangun hubungan yang baik dengan agama lain. ${ }^{9}$ Fredik Melkias Boiliu melakukan penelitian tentang "model pendidikan yang cocok dalam masyarakat majemuk di Indonesia: pendidikan agama yang inlklusif dan multikultural, dengan hasil penelitian yang menunjukkan bahwa pengajaran agama harus menekankan nilai-nilai pluralisme dan kebersamaan. ${ }^{10}$ Penelitian lain juga dilakukan Boiliu, yang merekomendasikan hasil, bahwa PAK hadir di tengah masyarakat majemuk untuk melakukan amanat agung, dan sebagai alat pembentuk dan pemersatu bangsa di tengah masyarakat majemuk. ${ }^{11}$ Dengan demikian, perbedaan antara penelitian sebelum dan penelitian ini adalah membahas tentang membina sikap toleransi beragama dengan model pendidikan agama Kristen yang inklusif, multikultural, dialog dan damai sebagai pendekatan yang tepat untuk membina sikap toleransi beragama dalam kehidupan sehari-hari.

Penelitian ini bertujuan untuk memberikan pemahaman terkait sikap toleransi beragama pada seluruh masyarakat di Indonesia. Penelitian ini memberikan pemahaman dan kesadaran kepada pihak keluarga, sekolah, dan gereja, tentang tanggung jawab membina sikap toleransi beragama dalam kehidupan sehari-hari.

${ }^{6}$ Zulfiqri Sonis Rahmana, 'Resolusi Konflik Sosial Keagamaan Di Kota Bandung', Jurnal Studi Agama-Agamadan Lintas Budaya, 2.2 (2018), 162-73.

${ }^{7}$ Andik Wahyun Muqoyyidin, 'Potret Konflik Bernuansa Agama Di Indonesia (Signifikansi Model Resolusi Berbasis Teologi Transformatif)', Analisis, XII.2 (2012), 315-40.

8 Ricky Santosa Muharam, 'Membangun Toleransi Umat Beragama Di Indonesia Berdasarkan Konsep Deklarasi Kairo', Jurnal HAM, 11.2 (2020), 269-83.

${ }^{9}$ Herman Mohamad Rijal, 'Pembinaan Toleransi Antar Umat Beragama Dalam Perspektif Pendidikan Agama Islam Bagi Remaja Di Kota Kendari', All Izza: Jurnal Hasil-Hasil Penelitian, 13.2 (2018), 224-39.

10 Fredik Melkias Boiliu, 'Model Pendidikan Yang Cocok Dalam Masyarakat Majemuk Di Indonesia: Pendidikan Agama Yang Inklusif Dan Pendidikan Agama Yang Multikultural', 180-185.

11 Fredik Melkias Boiliu, 'Pendidikan Agama Kristen Berwawasan Kemajemuk Dalam Membina Sikap Toleransi Beragama Di Indonesia', in Prosiding (Sentani: STAPN, 2019), pp. 131-40. 


\section{METODE}

Penelitian menggunakan metode penelitian kajian pustaka. Menurut V Wiratna Sujarweni kajian pustaka berfungsi untuk membangun konsep atau teori yang menjadi dasar studi dalam penelitian ini. ${ }^{12}$ Bahan pustaka sebagai sumber informasi ilmiah dalam penelitian ini adalah buku-buku teks PAK atau umum, jurnal ilmiah PAK atau umum, dan hasil-hasil penelitian lain seperti skripsi, tesis, dan disertasi, serta sumber-sumber relevan lainnya. Metode pengumpulan data dalam penelitian ini juga menggunakan sumber primer, seperti Alkitab. Teknik analisi data dalam penelitian ini, penulis menggunakan teknik analisis isi yaitu menganilisis data secara mendalam dan menarik suatu kesimpulan.

\section{PEMBAHASAN}

\section{Kemajemukan Beragama di Indonesia}

Indonesia merupakan sebuah negara yang bangsanya sangat majemuk. Dalam hal ini, Indonesia terdiri dari beragam agama yakni Islam, Kristen, Katolik, Hindu, Budha Khonghucu, dan agama-agama lokal. Untuk memahami secara lebih dalam kemajemukan atau keanekaraman itu, tidak cukup hanya dengan mengetahui angkaangka yang secara umum dipakai sebagai indikator kemajemukan, tidak pula cukup hanya dengan mengetahui nama-nama agama, suku atas ras dan seni budaya. ${ }^{13}$ Sebab, kemajemukan itu sangatlah kompleks. Misalnya, kemajemukan agama. Untuk memahami kompleksitas dan dinamika di dalamnya, perlu diketahui dan dipahami, bahwa di dalam agama-agama itu terdiri pula dari aliran, kelompok dan pemikiran serta tradisi yang pada hal-hal tertentu ia menyangkut identitas yang beragam. Jadi, akhirnya kemajemukan agama itu menyangkut juga kepelbagaian dan perbedaan sejarah, konteks budaya, dan tradisi masyarakat di mana masing-masing agama itu hadir. ${ }^{14}$

Oleh sebab itu, kemajemukan yang semakin kompleks ketika dibicarakan di tataran doktrinal. Kemajemukan agama, misalnya selalu berhadapan dengan masalah klaim kebenaran. Artinya tentu dalam sebuah agama, terdiri dari kelompok-kelompok aliran sehingga di antara kelompok-kelompok itu, meskipun memiliki sejarah dan membaca kitab suci yang sama, namun masing-masing kelompok meiliki potensi untuk saling mendominasi. Identitas atau kepentingan kelompok adalah keniscayaan dalam relasi antar kelompok pada sebuah masyarakat majemuk. ${ }^{15}$

\section{Problematika Keberagaman Agama Eklusivisme}

Eklusivisme merupaan paham yang mempunyai kecenderungan untuk memisahkan diri dari masayakarat dan tidak mengakui yang lain, menutup orang lain un-

\footnotetext{
12 V.Wiratna Sujarweni, Metodeologi Penelitian (Yogyakarta: Pustaka Baru Perss, 2014), 75.

13 Fredik Melkias Boiliu, Fransiskus Irwan Widjaja, and Dewi Lidya Sidabutar, 'The Role of Christian Religious Education as AStrategy in Dating Radicalism of Religion in Indonesia', ADI International Conference Series, 2 (2021), 137-44.

${ }^{14}$ Fredik Melkias Boiliu, Dialektika Pendidikan Dan Agama Di Era Kontemporer (Yogyakarta: Litera, 2021), 307-324.

15 Djoys Anneke Rantung, Pendidikan Agama Kristen Dalam Kehidupan Masayarakat Majemuk (Yogyakarta: Lintang Rasi Aksara Books, 2017), 41-47.
} 
tuk menjadi bagian dari sebuah ruangan. Artinya, eksklusivisme merujuk pada cara pandang, paham atau ideologi kelompok mayarakat berhadapan dengan kelompok yang lain. Dalam hal ini, kelompok mayarakat itu bisa berdasar suku, agama, budaya, ras, afiliasi, politik, gender/orientasi seksual dan strata sosial ekonomi. Selain itu, ekslusivisme kelompok menunjuk pada cara pandang atau ideologi yang merasa lebih khusus, lebih benar, lebih superior, lebih agung, lebih murni dari kelompok yang lain. ${ }^{16}$ Ekslusivisme juga merupakan salah satu masalah di dalam masyarakat majemuk. Dalam hal ini, masyarakat majemuk yang terdiri dari orang-orang atau kelompok yang berasal dari latar belakang yang berbeda, akan mengalami masalah dalam berelasi, berkomunikasi, bergaul, bekerjasama, jika diantara kelompok saling mengklaim 'kekhususannya'. ${ }^{17}$

Ekslusivisme adalah sikap keagamaan yang memandang bahwa ajaran yang paling benar adalah agama yang dipeluknya, yang lainnya sesat. Eklektisisme adalah sikap keagamaan yang berusaha memilih dan mempertemukan berbagai ajaran agama yang dipandang baik dan cocok untuk dirinya sehingga format akhir dari sebuah agama menjadi semacam mozaik eklektik. Ekslusivisme dalam konteks Kristen mengasumsikan bahwa hanya orang Kristen yang mengakui Kristus yang diselamatkan. Artinya, bahwa dalam ekslusivisme Kristen, keselamatan hanya melalui Kristus dan Yesus Kristus satu-satunya jalan keselamatan. Dalam konteks Islam, eksklusivisme memberian pandangan bahwa hanya satu cara pandang atau satu cara penafsiran yang benar. Artinya pandangan yang benar itu adalah, sebagaimana diklaimnya, pandangannya sendiri, sementara pandangan yang lain salah dan sesat. ${ }^{18}$

\section{Prasangka, Stereotip, dan Diskriminasi}

Permasalahan lain yang sering timbul dalam permasalahan agama juga adalah tipe prasangka. Dalam hal ini, tipe prasanka ini dapat terjadi sebagian atau secara kolektif dan prasangka akan bermula dari "perasaan" belaka yang bila ditemukan bukti maka akan berubah. Namun, jika tidak ada upaya untuk mengetahui, itu akan berubah menjadi "kebenaran". Misalnya, prasangka dimulai karena ada perbedaan realitas dari kelompok A ke kelompok B dan perbedaan itu terkait dengan agama. Dengan demikian, jika dipelihara dan diwariskan dari generasi ke generasi maka pada tahap tertentu akan diterima sebagai "kebenaran".19

Dalam hal ini, akan dirasionalisasi, dikonstruksi kebenaran logisnya sehingga menjadi semacam isu yang terus hidup dalam logika kelompok. "Kebenaran" yang terus dikembangkan, dirasionalisasi dalam banyak kasus akan secara ekstrim berubah menjadi diskriminasi. Prasangka merupakan keyakinan subjektif, sedangkan seteoretip merupakan respon emosional kelompok tertentu terhadap kelompok lain. Diskriminasi merupakan tindakan sebagai manifestasi dari prasangka dan stereotip

\footnotetext{
${ }^{16}$ Ahmad Zamakhsari, 'Teologi Agama-Agama Tipologi Tripolar; Eksklusivisme, Inklusivisme Dan Kajian Pluralisme', Tsaqofah; Jurnal Agama Dan Budaya, 18.1 (2020), 35-51.

17 Rantung, 45-46.

18 Imam Hanaf, 'Eksklusivisme, Inklusivisme, Dan Pluralisme: Membaca Pola Keberagamaan Umat Beriman', Al-Fikra: Jurnal Ilmiah Keislaman, 10.2 (2011), 388-409.

19 Rantung, 44.
} 
tersebut. Dengan demikian, kita mendapat gambaran bahwa prasangka, stereotip dan diskiriminasi adalah masalah dalam relasi antara kelompok dalam sebuah masyarakat majemuk. ${ }^{20}$ Artinya, bahwa prasangka, stereotip dan diskriminasi berpotensi untuk memicu konflik dalam masyarakat majemuk khususnya keberagaman agama.

\section{Beban-beban Sejarah}

Terkait dengan permasalahan antarumat beragama di Indonesia, maka bebanbeban sejarah juga merupakan faktor terjadinya permasalahan, sebab masyarakat majemuk terjadi melalui proses yang panjang. Dalam konteks Indonesia, beberapa wilayah dulunya merupakan unit berbasis suku dengan adat istiadat yang sama. Namun transmigrasi, pertukaran ekonomi, hingga era desentralisasi dengan pembentukan daerah pemerintahan baru menjadi beberapa faktor yang memungkinkan terjadinya pluralisasi. Studi postkolonial, misalnya, ingin menunjukkan apakah hubungan atau bentuk identitas yang ada, terutama di bekas jajahan, dalam banyak hal merupakan warisan kolonial. Agama Kristen di Indonesia, misalnya, diidentifikasikan oleh sebagian non-Kristen sebagai agama kolonial. Orang-orang Tionghoa dan penganut agama Konfusianisme juga menanggung beban sejarah mereka sendiri, terkait dengan periode revolusi dan persaingan ekonomi. Hubungan Islam dan Kristen seringkali tidak harmonis, karena sekelompok orang mencoba menghubungkannya dengan sejarah Perang Salib yang sangat jauh. ${ }^{21}$

Dengan demikian, sejarah pertemuan antar kelompok-kelompok yang berbeda dalam konteks keagamaan merupakan faktor penting yang sangat mempengaruhi pendapat dan cara pandang antar kelompok dalam suatu hubungan sekarang ini. Artinya mewarnai ketegangan, konflik dan kerusuhan hubungan antar kelompok yang berbeda selain dari faktor sosial, politik dan ekonomi yang faktual saat ini, trauma masa lalu dan dendam dalam perjumpaan sejarah merupakan faktor penting yang menentukan kualitas hubungan masyarakat yang majemuk.

\section{Model pendidikan agama Kristen berwawasan majemuk Model Inklusivisme}

Model PAK yang inklusif merupakan keterbukaan sikap dalam menerima keberbedaan dengan tetap berinteraksi dalam kehidupan sehari-hari dalam konteks agama yang beraneka ragam, atau disebut multikultural. Model PAK yang inklusif juga merupakan sikap bagaimana seseorang dapat menerima keberbedaan dengan ikut aktif dalam kehidupan kebinekaan. Hal ini akan memberikan sikap pada semua orang dalam tataran menghargai dan menghormati antar sesama. ${ }^{22}$ Oleh sebab itu, untuk membangun kesadaran dalam perbedaan yang ada dan menjadi bagian dari upaya mengelola keragaman serta upaya bina damai maka model PAK yang inklusif merupakan proses transformasi dari masa krisis di mana kelompok-kelompok masyarakat

\footnotetext{
20 Rantung, 45.

${ }^{21}$ N.K Atmadja Hardianto, Dialog Dan Edukasi: Keluarga Kristen Dalam Masyarakat Indonesia (Jakarta: BPK Gunung Mulia, 2012), 14-24.

22 Boiliu, 'Model Pendidikan Yang Cocok Dalam Masyarakat Majemuk Di Indonesia: Pendidikan Agama Yang Inklusif Dan Pendidikan Agama Yang Multikultural', 180-185.
} 
belum memahami pentingnya membina sikap toleransi beragam di Indonesia. ${ }^{23}$ Dalam hemat penulis model PAK yang inklusif ini bisa dapat di terapan di lingkungan keluarga, sekolah, gereja dan di lingkungan masyarakat majemuk. Sebab akan sangat efektif dalam membina sikap toleransi beragama.

Model PAK yang inklusif dapat dijadikan sebagai alternatif solusi menggantikan pembelajaran agama konfensional yang eksklusif sebab memiliki tujuan untuk mengubah paradigma PAK yang melihat diri sendiri ke melihat diri dalam keberadaannya dengan orang lain, sebagai strategi pembelajaran mengutamakan penghargaan dan penggelolaan keragaman, untuk membina sikap toleransi beragama dalam lingkup masyarakat majemuk, dan dapat membangun kehidupan bersama yang harmoni dalam perbedaan. Model PAK yang iklusif dalam tataran pelaksaannya tidak membeda-bedakan individu berdasarkan latar belakang agama, pendekatan ini untuk membangun dan mengembangkan sebuah lingkungan yang semakin terbuka, mengajak masuk dan mengikutsertakan semua orang dengan berbagai perbedaan yang ada. ${ }^{24}$ Model ini, dapat mengajarkan tentang bagaimana menghargai perbedaan antara agama yang satu dengan agama yang lain dan peka akan nilai-nilai kemanusiaan secara universal, memberikan wawasan tentang kehidupan secara utuh dan memberikan kesadaran bahwa tujuan hidup tertinggi adalah mengabdi kepada sesama, mengajak untuk merefleksikan realitas kemajemukan, menekankan nilai-nilai pluralisme, serta kebersamaan, dan dapat membebaskan kita dari sekat-sekat primordial, sehingga tidak melemahkan kemampuan bertoleransi dan menguatkan fanatisme. ${ }^{25}$

\section{Model Multikultural}

PAK Multikultural konteks Indonesia terletak pada kesiapan mengerjakan perilaku moderat untuk membangun kebermartabatan hidup. Keadaan ini, sekaligus menjadi penghormatan terhadap setiap agama yang ada, yang juga memiliki upaya memaknai kehidupan. Prinsip penghormatan terhadap agama dengan nilai-nilai yang dikembangkan di dalamnya tentu tidak serta merta membuat PAK tidak boleh mengkritisi setiap agama yang ada. Menurut I Made Saurdana PAK multikultur meru-pakan wilayah atau wadah untuk membangun solidaritas dan intimitas dalam berbagai keragaman yang ada. ${ }^{26}$ Selaras dengan ini, Fransiskus Irwan Widjaja PAK multikultural menekankan bahwa setiap individu dalam seluruh aspek kehidupannya, perkembangan hidupnya difokuskan pada upaya menolong atau menghidupkan atau menumbuhkan setiap orang bertumbuh dalam pola Yesus Kristus. ${ }^{27}$ Bagi Slamet

\footnotetext{
23 Yance Z. Rumahuru, 'Mengembangkan Pendidikan Agama Inklusif Sebagai Solusi Pengelolaan Keragaman Di Indonesia', Jurnal Taruna Bhakti, 1.1 (2018), 59-68.

${ }^{24}$ Boiliu, 'Model Pendidikan Yang Cocok Dalam Masyarakat Majemuk Di Indonesia: Pendidikan Agama Yang Inklusif Dan Pendidikan Agama Yang Multikultural'.

25 Jacob Messakh and Fredik Melkias Boiliu, 'Menjadi Guru Pendidikan Agama Kristen Yang Inklusif (Korelasi Panggilan, Kompetensi Dan Mengajar)', Jurnal Education and Development Institut Pendidikan Tapanuli Selatan, 9.1 (2021), 1-7.

26 I Made Suardana, 'Mengurai Landasan Konseptual Pendidikan Agama Kristen Multikultural Dalam Konteks Indonesia', KURIOS (Jurnal Teologi Dan Pendidikan Agama Kristen), 6.2 (2020), 346-66.

${ }^{27}$ Fransiskus Irwan Widjaja, 'Pluralitas Dan Tantangan Misi: Kerangka Konseptual Untuk Pendidikan Agama Kristen Dalam Masyarakat Majemuk', Pendidikan Agama Kristen Regula Fidei, 4.1 (2019), 591.
} 
Sentoso, PAK Multikultual tidak pernah terbatas pada pengajaran teoretis melalui kata-kata dan ide-ide abstrak, juga bukan hanya sarana untuk menyebarkan pengetahuan tentang agama Kristen. ${ }^{28}$ Dengan demikian, PAK Multikultual menjadi upaya yang dibangun dalam kesadaran bersama, berprilaku moderat dengan menempatkan pemberdayaan kehidupan menjadi bingkai utamanya.

Boiliu mengatakan bahwa Model PAK multikultural merupakan kesadaran bersama untuk mewujudkan pembangunan dan pemberdayaan hidup yang berkelanjutan melalui upaya menyinergikan tujuan PAK dalam perspektif iman Kristen dengan kemajemukan dalam bingkai inklusif-rekonstruktif yang berkesinambungan. ${ }^{29}$ Selaras dengan ini, menurut Rolina A.E Kaunang, Sylvana Talangamin pendidikan multikultural harus dapat membangun paradigma peserta didik agar terbiasa dengan kehidupan yang majemuk dalam kehidupan sehari-hari. Bagi mereka guru PAK sebagai ujung tombok untuk membentuk generasi emas yang mampu bekerja sama dengan sesama dalam berbagai perbedaan. ${ }^{30}$ Yanice Janis dan Gerry Nelwan menga-takan sebagai salah satu upaya strategis dalam membangun masyakarakat multi-kultural di Indonesia. Bagi mereka pendidikan multikultural harus dikembangkan mulai dari gereja-gereja di Indonesia melalui lima dimensi, yaitu: dimensi integrasi isi, pereduksian prasangka, konstruksi ilmu pengetahuan, pendidikan yang adil dan pemberdayaan budaya sekolah. ${ }^{31}$ Fajar Setyaning Dwi Putra dan Sapriya menegaskan bahwa pendidikan multikultural sangata penting untuk diterapkan dalam pembelajaran di sekolah untuk mengajarkan siswa menjadi manusia Indonesia yang pancasilais, mampu mengerti dan memahami pluralitas di Indonesia, menanamkan cara hidup untuk menghormati dengan tulus, dan hidup toleran dalam keberagaman agama yang ada.32 Dengan demikian, pendidikan multikultural penerapannya dalam kehidupan sehari-hari dimulai dari lingkungan gereja dan sekolah karena kedua lembaga ini memiliki peran yang sangat penting dalam kehidupan masyarakat majemuk.

\section{Model Dialog}

Dalam konteks kemajemukan agama se-Asia, istilah dialog dipakai sebagai metafora inklusif bagi hubungan antar agama yang positif diantara masyarakat yang berbeda tradisi imannya, yang sudah menjadi praktik aktual diantara kelompok masyarakat yang berbeda. ${ }^{33}$ Dalam hal ini, dialog antar agama telah terjadi di Asia dengan berbagai bentuk yaitu: dialog menjadi suatu kehadiran yang positif diantara yang lain demi kebersamaan atau berada dengan yang lainnya; dialog melakukan aksi bersama

\footnotetext{
28 Slamet Santoso, 'Tinjauan Kritis Terhadap Pendidikan Agama Multikultural Barbara Wilkerson', Jurnal ABDIEL, 2.2 (2018), 56-71.

${ }^{29}$ Boiliu, 'Model Pendidikan Yang Cocok Dalam Masyarakat Majemuk Di Indonesia: Pendidikan Agama Yang Inklusif Dan Pendidikan Agama Yang Multikultural', 186.

30 Rolina A.E Kaunang and S.S Sylvana, Praktik Pendidikan Multikultural: Pendekatan Progresif Dalam Mewujudkan Generasi Emas Yang Mampu Bekerja Sama Dalam Segala Perbedaan (Yogyakarta: Litera, 2021), 289.

31 Yanice Janis and Gerry Nelwan, Pendidikan Multikultural: Upaya Gereja Dalam Menjaga Hubungan Antar Umat Beragama (Yogyakarta: Litera, 2021), 300-304.

32 Fajar Setyaning Dwi Putra and Sapriya, Perkembangan Mutakhir PKN Sebagai Wahan Pendidikan Multikultural Di Era Digital (Yogyakarta: Litera, 2021), 37.

${ }^{33}$ Hope S Antoni, Peendidikan Kristiani Kontekstual (Jakarta: BPK Gunung Mulia, 2012), 92-94.
} 
dalam menjawab persoalan yang menjadi keprihatinan masyarakat tanpa memandang latarbelakang kepercayaan dan agama; dialog berbagi dan bertukar pikiran melalui studi bersama agar saling memahami, demi memperluas wawasan dan perspektif; dialog pengalaman yakni membagikan kedalam pengalaman kemanusiaan dan keagamaan yang mendalam untuk saling memperkaya iman dan spiritualitas.

Model dialog digunakan untuk membangun komunikasi yang baik antarumat beragama dan menjadikan keberagaman agama sebagai kesempatan dimana setiap umat beragama dapat saling diperkaya dan memperkaya. Selain itu, umat beragama juga berusaha meninggalkan sikap arogansi dan intoleransi yang banyak terjadi dalam sejarah serta mengoreksi ekslusivisme dalam semua agama secara kritis. ${ }^{34}$ Sikap terbuka dan dialog bersama harus dibangun dan dikembangkan karena dengan berdialog kita bisa menerima perbedaan untuk saling menghormati dan saling menghargai sehingga dapat menghasilkan kedewasan iman semua pihak serta menjadi katalisator yang kuat untuk kebaikan. Dalam pelaksanaan dialog, setiap umat beragama berupaya untuk saling mengerti, dan berbicara atas dasar komitmen bersama terhadap kesejahteraan umat manusia dan lingkungan. ${ }^{35}$ Masing-masing umat beragama berpikir untuk melakukan hal yang dapat mensejahterakan kehidupan manusia keseluruhan bukan kepentingan pribadi atau kepentingan kelompok tertentu. Dialog antar umat beragama akan gagal bila salah satu agama secara apriori memandang dirinya lebih unggul dari segala hal sehingga agama tersebut tidak mau dan tidak mampu belajar dari agama lain.

\section{Model Damai}

Damai merupakan sebuah istilah yang sudah sering diucapkan dan didengar. Dalam Kamus Besar Bahasa Indonesia "damai” diartikan sebagai "tidak ada perang, keadaan yang aman dan rukun". Kedamaian secara luas yaitu ketenangan tiada gangguan. Terkait dengan pengertian damai di atas, maka dapat dipahami bahwa model damai sebagai rujukan untuk digunakan dalam membina sikap toleransi beragama di Indonesia. Feryanto ${ }^{36}$ mengatakan bahwa hidup damai merupakan suatu bentuk pemberdayaan manusia dengan keterampilan tingkah laku dan pengetahuan yang meliputi beberapa hal yaitu: membangun, menegakan dan memperbaiki hubungan dalam segal aspek kehidupan; mengembangkan pendekatan-pendekatan yang bersifat positif; menciptakan lingkungan yang aman secara fisik dan emosional; membangun kehidupan yang aman secara berkelanjutan. Selaras dengan ini, Agus Akhmadi mengatakan bahwa hidup damai dalam lingkungan masyarakat majemuk merupakan untuk saling menghargai dengan penuh kedamaian pada semua anggota komunitas dengan menerapkan prinsip kesetaraan dan tidak diskriminatif. ${ }^{37}$ Dengan

\footnotetext{
${ }^{34}$ Dwi Wahyuni, 'Gerakan Dialog Keagamaan: Ruang Perjumpaan Antar Umat Beragama Di Kota Bandung Religious', Jurnal Studi Agama-Agama Dan Lintas Budaya, 3.2 (2019), 188-97.

35 Harianto GP, 89.

${ }^{36}$ Feryanto, 'Nilai-Nilai Perdamaian Pada Masyarakat Multikultural', Jurnal Studi Agama-Agama, 1.1 (2018), 20-28.

${ }^{37}$ Agus Akhmadi, 'Moderasi Beragama Dalam Keragaman Indonesia', Jurnal Diklat Keagamaan, 13.2 (2019), 45-55.
} 
demikian, dapat dipahami bahwa tujuan dari hidup damai adalah memahami dan mengerti orang lain dalam keberbedaan dari hal-hal yang mendasari pemikiran mereka supaya bermanfaat sebagai jalan kehidupan secara universal dalam mengembangkan fondasi kerja sama di tengah keberagaman yang ada.

Menurut Kresbinol Labobar model damai harus diterapkan dalam kehidupan sehari-hari sebagai pendekatan untuk membina sikap toleransi beragama ${ }^{38}$ melalui beberapa hal. Pertama, menciptakan koinonia (persekutuan). Secara umum Koinonia diartikan sebagai persekutuan. Dalam iman Kristen, istilah koinonia memberi penekanan makna bahwa sesungguhnya umat manusia adalah keluarga besar Allah. Sebagai satu keluarga besar Allah manusia harus mampu menyatakan kehidupan yang rukun dan damai. Artinya sebagai keluarga besar Allah, manusia harus bertanggung jawab untuk menghadirkan bentuk kehidupan yang serasi, selaras dan seimbang antar pribadi dan golongan yang terdapat dalam masyarakat majemuk. Kedua, menghadirkan tanda-tanda kerajaan Allah. Kehidupan yang damai adalah gaya hidupan yang bebas dari perseteruan, perselisihan atau yang dikenal dengan konflik maka sesungguhnya melalui damai akan hadir kerajaan Allah di dalam kehidupan manusia. Artinya, manusia harus bertanggungjawab untuk dalam menghadirkan kehidupan aman, tentram dan harmonis dalam masyarakat majemuk. Dalam penerapan model damai untuk membina sikap toleransi beragama maka ada beberapa prinsip yang harus diterapkan yaitu: Dialog (menciptakan komunikasi); adil, bersikap adil; mengasihi (menjalin kasih); aman (rasa tentram). ${ }^{39}$ Dengan demikian, model damai digunakan untuk kerukunan hidup sebagai umat Tuhan dengan mewujudkan kehidupan manusia yang beragama. Sebab sesungguhnya setiap agama mengajarkan agar manusia senantiasa berusaha untuk hidup saling mengasihi, mencintai, menghargai, menghormati, menjalin kerja sama, bertoleransi dan melakukan perbuatan baik lainnya dalam bergaul dengan sesama.

\section{Sikap Toleransi Beragama di Indonesia}

Toleransi beragama merupakan toleransi yang dilakukan menyangkut dengan keyakinan yang berhubungan dengan ajaran-ajaran agama, yakni memunculkan sikap untuk memberikan kesempatan kepada umat selain agamanya, juga untuk beribadah sesuai dengan yang diyakini. Toleransi antar umat beragama juga merupakan suatu mekanisme sosial yang dilakukan manusia dalam menyikapi keragaman dan pluralitas agama. Dalam kehidupan sehari-hari, toleransi dapat dilihat secara nyata dari aktivitas-aktivitas sosial yang dilakukan sehari-hari di lingkungan masyarakat secara gotong royong baik itu kegiatan yang berkaitan dengan kepentingan umum maupun kepentingan perseorangan. ${ }^{40}$ Hakikat toleransi, intinya, yaitu usaha dalam hal kebaikan, khususnya pada kemajemukan agama yang memiliki tujuan tercapainya kerukunan, baik intern agama maupun antar agama. Dalam hal ini, tujuan kerukunan an-

\footnotetext{
38 Kresbinol Labobar, Dialektika Pendidikan Dan Agama Di Era Kontemporer (Model Damai: Resolusi Konflik Menuju Indonesia Damai) (Yogyakarta: Litera, 2021), 262-287.

${ }^{39}$ Kresbinol Labobar.

40 Ika Fatmawati Faridah, 'Toleransi Antar Umat Beragama Masyarakat Perumahan', Jurnal Komunitas, 5.1 (2013), 15.
} 
tarumat beragama dibagi menjadi empat ${ }^{41}$, yaitu: Meningkatkan keimanan dan ketakwaan terhadap masingmasing agama; Mewujudkan stabilitas nasional yang mantap; Menjunjung dan menyukseskan pembangunan; Memelihara dan mempererat rasa persaudaraan antar umat beragama. Prinsip toleransi antar umat beragama untuk mencapai keadaan yang tentram. Dalam hal ini, ada beberapa prinsip dalam perlu diperhatikan terkait dengan toleransi beragama di Indonesia. Pertama, kebebasan beragama, merupakan hak asasi manusia yang paling penting dalam kehidupannya. Artinya dalam kehidupan beragama, manusia sebagai mahluk yang beragama bebas memilih kepercayaan/agama yang dianutnya. Kebebasan beragama yang dimaksud disini ialah tidak menuntut namun bebas menganut yang dirinya menganggap paling benar. Kedua, penghormatan pada eksistensi agama lain, menunjukkan sikap yang toleransi dengan memberikan kebebasan dan saling menghormati kepada perbedaan ajaran yang dianut. Ketiga, setuju di dalam perbedaan, menunjukkan sikap saling menerima dan mendukung dalam perbedaan yang ada. ${ }^{42}$

Terkait dengan sikap toleransi beragama di Indonesia, dalam membina sikap toleransi yang baik dalam kehidupan sehari-hari dalam masyarakat majemuk perlu pendidikan agama yang berwawasan majemuk. Oleh sebab itu, model PAK berwawasan majemuk sangat tepat untuk membina sikap toleransi beragama di Indonesia. Model PAK yang berwawasan majemuk dapat dilaksanakan melelui beberapa hal. Pertama, memiliki sikap yang membangun kesadaran seseorang atau kelompok terhadap keberbedaan agama untuk memiliki kehidupan bersama yang damai. Dalam membina sikap toleransi beragama melalui PAK berwawasan mejemuk dengan model ilklusif harus diterapkan pada lingkunga keluarga, sekolah, gereja dan masyarakat majemuk. Model ini, dapat mengajarkan tentang bagaimana menghargai sesama manusia dalam perbedaan antara agama yang satu dengan agama yang lain dan sadar akan nilai-nilai kemanusiaan secara universal, memberikan wawasan tentang kehidupan secara utuh dan memberikan pemahaman. Kedua, memiliki kesadaran bersama merupakan model PAK yang multikultural, dilaksanakan untuk mewujudkan pembangunan dan pemberdayaan hidup yang berkelanjutan dalam kehidupan sehari-hari di tengah perbedaan yang ada dalam membina sikap torensi beragama. Model ini juga, dilaksanakan untuk membangun kesadaran bersama, berperilaku moderat dengan menempatkan pemberdayaan kehidupan menjadi bingkai utamanya dengan saling menghormati, menghargai, mengasihi, dan membantu. Hal ini harus terus-menerus dilakukan dalam kehidupan sehari-hari di lingkungan keluarga, sekolah, gereja dan masyarakat majemuk.

Ketiga, membangun komunikasi merupakan model dialog dalam PAK berwawasan majemuk yang dilakukan pada kehidupan sehari-hari antar umat beragama untuk membangun sikap toleransi beragama. Model ini, menjadikan keberagaman agama sebagai kesempatan dimana setiap umat beragama dapat saling belajar satu sama

\footnotetext{
${ }^{41}$ Khotimah, 'Agama Dan Civil Society', Jurnal Ushuluddin, XXI.1 (2014), 121-32.

42 Jamaludin and Adon Nasrullah, Agama Dan Konflik Sosial: Studi Kerukunan Beragama, Radikalisme Dan Konflik Antara Umat Beragama (Bandung: Pustaka Setia, 2015), 109-111.
} 
lain. pelaksanaan model dialog dilakukan dalam kehidupan sehari-hari di tengah perbedaan yang ada untuk meninggalkan sikap arogansi yang tidak saling menghargai, tidak menghormati, dan tidak mengasihi satu sama lain dan juga memperbaiki pemahaman yang menganggap agamanya paling benar dan agama yang lain tidak benar. Keempat, memiliki kehidupan bersama yang keadaan aman dan rukun dalam kehidupan sehari-hari. PAK berwawasan mejemuk dengan model damai dilaksanakan untuk menghadirkan bentuk kehidupan yang serasi, selaras dan seimbang antar agama yang terdapat dalam masyarakat majemuk. Model damai ini juga berusaha untuk hidup saling mengasihi, mencintai, menghargai, menghormati, menjalin kerja sama, bertoleransi dan melakukan perbuatan baik lainnya dalam bergaul dengan sesama.

\section{KESIMPULAN}

Terkait dengan pembahasan model PAK berwawasan majemuk dalam membina sikap toleransi beragama di Indonesia, maka dapat disimpulkan, ada beberapa hal yang dibutuhkan dalam membina sikap toleransi beragama di Indonesia. Pertama, membutuhkan kesadaran bersama untuk memiliki kehidupan bersama yang harmonis dengan saling menghormati, menghargai, mengasihi dan membantu atau menolong. Kedua, membangun perilaku yang menempatkan pemberdayaan kehidupan menjadi bingkai utamanya dalam kehidupan sehari-sehari. Ketiga, membangun komunikasi yang baik antar umat beragama dalam kehidupan sehari-hari. Keempat, menciptakan kehidupan yang aman dan rukun dalam kehidupan sehari-hari di tengah perbedaan yang ada.

\section{REFERENSI}

Akhmadi, Agus, 'Moderasi Beragama Dalam Keragaman Indonesia', Jurnal Diklat Keagamaan, 13.2 (2019), 45-55

Antoni, Hope S, Peendidikan Kristiani Kontekstual (Jakarta: BPK Gunung Mulia, 2012)

BM, St. Aisyah, 'Konfik Sosial Dalam Hubungan Antar Umat Beragama', Jurnal Dakwah Tabligh, 15.2 (2014), 189-208

Boiliu, Fredik Melkias, Dialektika Pendidikan Dan Agama Di Era Kontemporer (Yogyakarta: Litera, 2021)

_-_ , 'Model Pendidikan Yang Cocok Dalam Masyarakat Majemuk Di Indonesia: Pendidikan Agama Yang Inklusif Dan Pendidikan Agama Yang Multikultural', in Prosiding Seminar Nasional Universitas Kristen Indonesia Jakarta, 2018, pp. 17890

_-_, 'Pendidikan Agama Kristen Berwawasan Kemajemuk Dalam Membina Sikap Toleransi Beragama Di Indonesia', in Prosiding (Sentani: STAPN, 2019), pp. 13140

Boiliu, Fredik Melkias, Fransiskus Irwan Widjaja, and Dewi Lidya Sidabutar, 'The Role of Christian Religious Education as AStrategy in Dating Radicalism of Religion in Indonesia', ADI International Conference Series, 2 (2021), 137-44

Feryanto, 'Nilai-Nilai Perdamaian Pada Masyarakat Multikultural', Jurnal Studi Agama-Agama, 1.1 (2018), 20-28

GP, Harianto, Pendidikan Agama Kristen Dalam Alkitab \& Dunia Pendidikan Masa Kini (Yogyakarta: ANDI, 2012) 
Hanaf, Imam, 'Eksklusivisme, Inklusivisme, Dan Pluralisme: Membaca Pola Keberagamaan Umat Beriman', Al-Fikra: Jurnal Ilmiah Keislaman, 10.2 (2011), 388-409

Hardianto, N.K Atmadja, Dialog Dan Edukasi: Keluarga Kristen Dalam Masyarakat Indonesia (Jakarta: BPK Gunung Mulia, 2012)

Ika Fatmawati Faridah, 'Toleransi Antar Umat Beragama Masyarakat Perumahan', Jurnal Komunitas, 5.1 (2013), 15

Jamaludin, and Adon Nasrullah, Agama Dan Konflik Sosial: Studi Kerukunan Beragama, Radikalisme Dan Konflik Antara Umat Beragama (Bandung: Pustaka Setia, 2015)

Janis, Yanice, and Gerry Nelwan, Pendidikan Multikultural: Upaya Gereja Dalam Menjaga Hubungan Antar Umat Beragama (Yogyakarta: Litera, 2021)

Kaunang, Rolina A.E, and S.S Sylvana, Praktik Pendidikan Multikultural: Pendekatan Progresif Dalam Mewujudkan Generasi Emas Yang Mampu Bekerja Sama Dalam Segala Perbedaan (Yogyakarta: Litera, 2021)

Khotimah, 'Agama Dan Civil Society', JURNAL USHULUDDIN, XXI.1 (2014), 121-32

Kresbinol Labobar, Dialektika Pendidikan Dan Agama Di Era Kontemporer (Model Damai: Resolusi Konflik Menuju Indonesia Damai) (Yogyakarta: Litera, 2021)

Messakh, Jacob, and Fredik Melkias Boiliu, 'Menjadi Guru Pendidikan Agama Kristen Yang Inklusif (Korelasi Panggilan, Kompetensi Dan Mengajar)', Jurnal Education and Development Institut Pendidikan Tapanuli Selatan, 9.1 (2021), 1-7

Muharam, Ricky Santosa, 'Membangun Toleransi Umat Beragama Di Indonesia Berdasarkan Konsep Deklarasi Kairo', Jurnal HAM, 11.2 (2020), 269-83

Muqoyyidin, Andik Wahyun, 'Potret Konflik Bernuansa Agama Di Indonesia (Signifikansi Model Resolusi Berbasis Teologi Transformatif)', Analisis, XII.2 (2012), 315-40

Putra, Fajar Setyaning Dwi, and Sapriya, Perkembangan Mutakhir PKN Sebagai Wahan Pendidikan Multikultural Di Era Digital (Yogyakarta: Litera, 2021)

Rahmana, Zulfiqri Sonis, 'Resolusi Konflik Sosial Keagamaan Di Kota Bandung', Jurnal Studi Agama-Agamadan Lintas Budaya, 2.2 (2018), 162-73

Rantung, Djoys Anneke, Pendidikan Agama Kristen Dalam Kehidupan Masayarakat Majemuk (Yogyakarta: Lintang Rasi Aksara Books, 2017)

Retnowati, 'Agama, Konflik Dan Integrasi Sosial Refleksi Kehidupan Beragama Di Indonesia: Belajar Dari Komunitas Situbondo Membangun Integrasi Pasca Konflik', Sangkep Jurnal Sosial Keagamaan, 1.1 (2018), 3-28

Rijal, Herman Mohamad, 'Pembinaan Toleransi Antar Umat Beragama Dalam Perspektif Pendidikan Agama Islam Bagi Remaja Di Kota Kendari', All Izza: Jurnal Hasil-Hasil Penelitian, 13.2 (2018), 224-39

Rumahuru, Yance Z., 'Mengembangkan Pendidikan Agama Inklusif Sebagai Solusi Pengelolaan Keragaman Di Indonesia', Jurnal Taruna Bhakti, 1.1 (2018), 59-68

Santoso, Slamet, 'Tinjauan Kritis Terhadap Pendidikan Agama Multikultural Barbara Wilkerson', Jurnal ABDIEL, 2.2 (2018), 56-71

Sanusi, Anwar, Metode Penelitian Bisnis (Jakarta: Salemba empat, 2016)

Suardana, I Made, 'Mengurai Landasan Konseptual Pendidikan Agama Kristen Multikultural Dalam Konteks Indonesia', KURIOS Jurnal Teologi Dan Pendidikan Agama Kristen, 6.2 (2020), 346-66

Sujarweni, V.Wiratna, Metodeologi Penelitian (Yogyakarta: Pustaka Baru Perss, 2014) Syukron, Buyung, 'Agama Dalam Pusaran Konflik (Studi Analisis Resolusi Terhadap Munculnya Kekerasan Sosial Berbasis Agama Di Indonesia)', RI'AYAH, 2.2 (2017), 1-27 
Wahyuni, Dwi, 'Gerakan Dialog Keagamaan: Ruang Perjumpaan Antar Umat Beragama Di Kota Bandung Religious', Jurnal Studi Agama-Agama Dan Lintas Budaya, 3.2 (2019), 188-97

Widjaja, Fransiskus Irwan, 'Pluralitas Dan Tantangan Misi: Kerangka Konseptual Untuk Pendidikan Agama Kristen Dalam Masyarakat Majemuk', Pendidikan Agama Kristen Regula Fidei, 4.1 (2019), 591

Yunus, Firdaus M, '“Konflik Agama Di Indonesia Problem Dan Solusi Pemecahannya,"' Substantia, 16.2 (2014), 217-28

Zamakhsari, Ahmad, 'Teologi Agama-Agama Tipologi Tripolar; Eksklusivisme, Inklusivisme Dan Kajian Pluralisme', Tsaqofah; Jurnal Agama Dan Budaya, 18.1 (2020), 35-51 